\title{
Radioautographic localization of inhibition of protein synthesis in specific regions of monkey brain
}

\author{
H. EICHENBAUM, C. M. BUTTER AND B. W. AGRANOFF
}

Neuroscience Laboratory, Departments of Psychology and Biological Chemistry, University of Michigan, Ann Arbor, Mich. 48104 (U.S.A.)

(Accepted July 2nd, 1973)

There is considerable evidence that antibiotic inhibitors of protein synthesis, injected intracranially before or just after a learning experience, block memory formation in goldfish ${ }^{1}$, chicks ${ }^{12}$, and mice $^{3}$. However, in none of these studies has the region of inhibition of protein synthesis been localized in anatomical structures. While fluorescein injections into specific mouse cerebral sites have been used to estimate where similarly injected antibiotic inhibitors might act $^{6}$ this procedure does not take into account possible differences between the diffusion of antibiotics such as puromycin or cycloheximide and that of the dye. Nor can this procedure measure the duration of action of the drug. In other studies, total incorporated radioactivity has been measured in each of 6 grossly dissected brain regions following brief incorporation of labeled amino acids preceded by intracerebral injection of an antimetabolite ${ }^{5}$.

A simple and more precise estimate of the region of inhibition should be possible by means of radioautography of brain sections following incorporation of labeled amino acids. The present report describes localization of zones of protein synthesis inhibition produced by puromycin or cycloheximide, injected through chronically implanted cannulas into monkey cerebral cortex. The monkey was selected as the experimental animal for the present study because of previous observations that lesions in discrete regions of primate cerebral cortex produce specific and different deficits in learning tasks ${ }^{9,10}$. We are engaged in concomitant studies of the behavioral effects of localized inhibition of protein synthesis in the monkey brain.

Three male rhesus monkeys (Macaca mulatta, $4-5 \mathrm{~kg}$ ) were anesthetized with ketamine hydrochloride (Parke Davis, $25 \mathrm{mg} / \mathrm{kg}$ ) and chronically implanted under sterile conditions with stainless steel cannulas (23-gauge outer barrel, 27-gauge inner barrel). After exposure of the cranium, a small burr hole was made over the appropriate cortical area, the meninges were penetrated, and the cannula was lowered until the tip was 2-3 $\mathrm{mm}$ below the brain surface. The cannula was then secured with screws and dental cement. After a 1-2 week recovery period, antibiotics were injected via the cannulas into anesthetized monkeys. Puromycin dihydrochloride (Nutritional Biochemicals, $17 \mathrm{mg} / \mathrm{ml}$ neutralized with $\mathrm{NaHCO}_{3}$ in $0.154 \mathrm{M} \mathrm{NaCl}$ ) or cycloheximide 
(CXM, Actidione, Upjohn, $1 \mathrm{mg} / \mathrm{ml}$ in $0.154 \mathrm{M} \mathrm{NaCl}$ ) was injected in combination with hyaluronidase (Worthington, $1 \mathrm{mg} / \mathrm{ml}$ in $0.154 \mathrm{M} \mathrm{NaCl}$ ). The enzyme was added to facilitate intracerebral spread of the injected antimetabolite. Unless otherwise specified, $10 \mu \mathrm{l}$ of hyaluronidase in saline was injected, followed $30 \mathrm{~min}$ later by $50 \mu \mathrm{l}$ of puromycin or cycloheximide solution, each containing the same concentration of hyaluronidase. For comparison, other sites were injected with $10 \mu \mathrm{l}$ of saline followed by CXM without hyaluronidase, or with $10 \mu \mathrm{l}$ of hyaluronidase followed by an additional $50 \mu \mathrm{l}$ of hyaluronidase without CXM. The various injections were made at specified times before an injection into the femoral vein of $\left[{ }^{14} \mathrm{C}\right]$ amino acid dissolved in $3 \mathrm{ml}$ of saline. Following a $35-45 \mathrm{~min}$ labeling pulse, an overdose of ketamine was administered, and the animal was perfused with saline followed by $10 \%$ formalin. Following perfusion, the brain was blocked in the frontal stereotaxic plane and then removed from the skull. The blocked tissue remained in $10 \%$ formalin for 10 days and was then transferred to sucrose-formalin, until it sank. The tissue was next embedded in albumin gel, and 40-60 $\mu \mathrm{m}$ thick sections were cut. Every tenth section was mounted on a $2.5 \mathrm{in.} \times 3 \mathrm{in}$. glass slide and dried. The dried sections were placed in contact with Kodak No-screen X-ray film, which was exposed in a light-tight box for 6-7 weeks at room temperature and then discarded or stored for possible re-exposure. Films were developed with Kodak X-ray developer and fixer. Brain sections adjacent to those used for radioautography were mounted, stained with thionin, and examined for possible changes in histomorphology. Localized cortical zones of protein inhibition can clearly be visualized in the radioautograms (Fig. 1B and C). In each instance, the antibiotic-hyaluronidase solution was injected $1 \mathrm{~h}$ before the labeled amino acid injection. The diameter of the zone of inhibition produced by either antimetabolite with hyaluronidase was found to be $4-9 \mathrm{~mm}$ in the maximal extent. In general, inhibition is more easily seen in the gray matter, where basal labeling is heaviest, but inhibition in the white matter is also apparent (see Fig. 1B). Hyaluronidase itself appears to have no effect on protein labeling. Comparison of maximal diameter of zones of inhibition produced by CXM + hyaluronidase with those produced by CXM alone suggests that hyaluronidase does however enlarge the zone of protein synthesis inhibition (Fig. 1D), although the extent of the effect has not been established.

The time course of inhibition was examined by injecting antimetabolites at various times before the terminal labeling period (Fig. 1D-F). An injection of $50 \mu \mathrm{g}$ of CXM or of $850 \mu \mathrm{g}$ of puromycin, each in $50 \mu \mathrm{l}$, produced a marked zone of inhibition $1 \mathrm{~h}$ after injection. Inhibition following CXM injection was greatly diminished by $5 \mathrm{~h}$. In contrast, puromycin produced a marked degree of inhibition still present at $5 \mathrm{~h}$; after $24 \mathrm{~h}$ there was no remaining evidence of inhibition. A similar difference in the time course of protein synthesis block by cycloheximide and puromycin has been reported in goldfish ${ }^{11}$ and mouse ${ }^{2}$ brains.

Examination of thionin-stained sections taken from tissue in the region of each injection site revealed minimal vascular and phagocytic reaction attributable to cannula implantation. Some acute traumatic reaction, evidenced by proliferation of polymorphonuclear leucocytes, was observed at all injection sites. This reaction could 

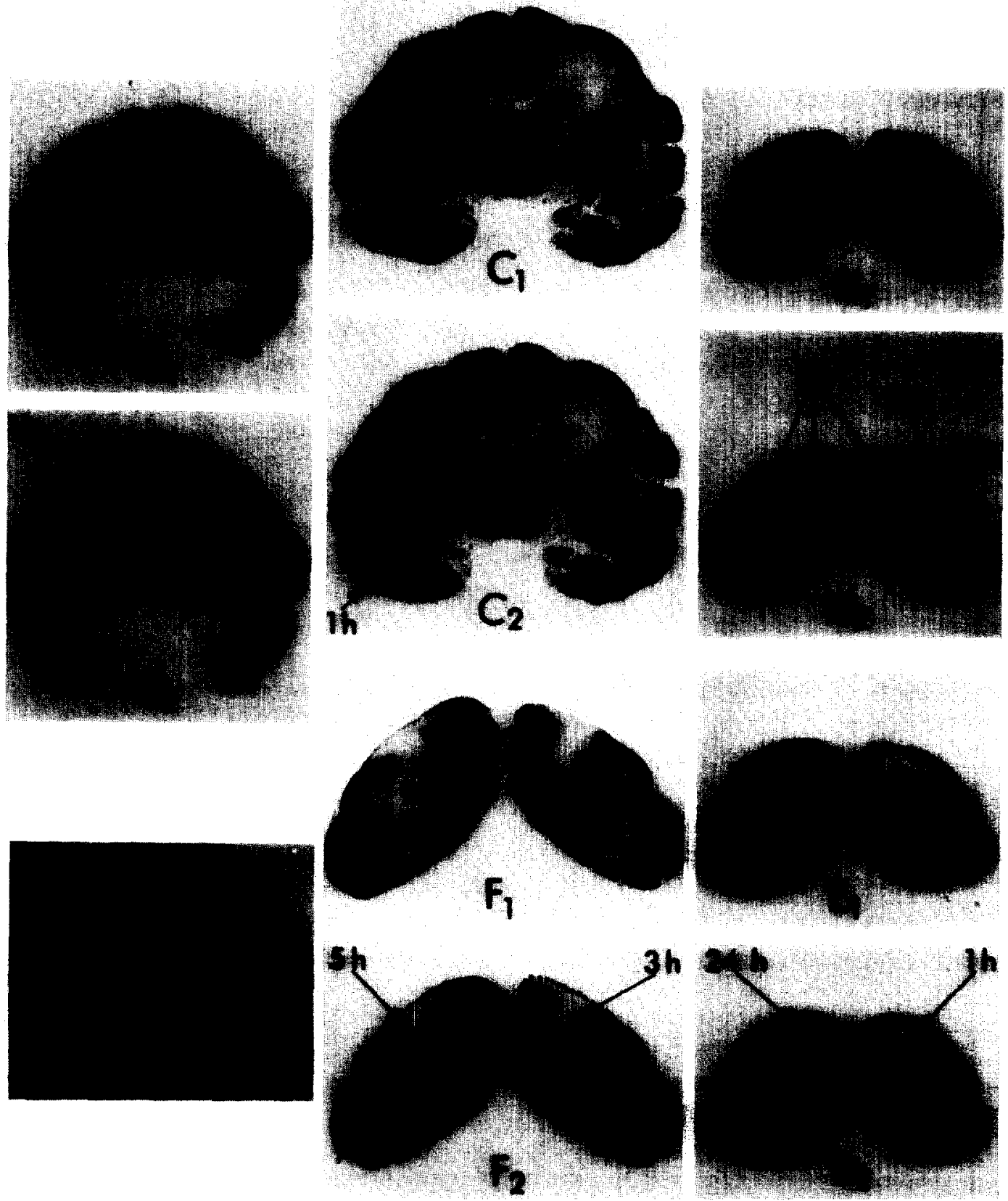

Fig. 1. Photographs (arranged clockwise from lower left) of a thionin-stained section (A) and radioautograms (B-F) showing regions of inhibition of protein synthesis at the site of cannula placements in monkey brain as described in text. The monkey used for Fig. 1 (except D) received $250 \mu \mathrm{Ci}$ of L-[U-14 C]leucine $(327 \mathrm{mCi} / \mathrm{mmole}$, New England Nuclear) $35 \mathrm{~min}$ prior to terminal perfusion. The monkey used for Fig. 1D received $250 \mu \mathrm{Ci}$ of L-[methyl-1/4 C]methionine $(9.75 \mathrm{mCi} / \mathrm{mmole}$, New England Nuclear) and the duration of the in vivo labeling pulse was $45 \mathrm{~min}$. In one of each pair of adjacent sections (about $600 \mu \mathrm{m}$ apart) the zone of inhibition is demarcated by a dotted line. A: thionin-stained section adjacent to those used for radioautograms in Fig. $B_{1}$ and $B_{2}$. Traumatic lesion produced by the cannula tip is circled. B: paired radioautograms showing zone of inhibition in prefrontal cortex produced by a $50 \mu \mathrm{l}$ injection containing $50 \mu \mathrm{g}$ of CXM $+50 \mu \mathrm{g}$ of hyaluronidase. $C$ : paired radioautograms showing zone of inhibition in inferotemporal cortex produced by a $50 \mu \mathrm{l}$ injection containing $850 \mu \mathrm{g}$ of puromycin and $50 \mu \mathrm{g}$ of hyaluronidase. D: paired radioautograms showing zones of inhibition produced in right striate cortex by injection of CXM t. hyaluronidase $1 \mathrm{~h}$ before labeling pulse, and in left striate cortex by injections of CXM alone (two sites) also $1 \mathrm{~h}$ before labeling pulse. Sites of CXM + hyaluronidase injected 5 and $24 \mathrm{~h}$ before labeling pulse are seen as small holes in the right striate cortex. E and F: paired radioautograms showing zones of inhibition in striate cortex produced by puromycin + hyaluronidase injected $1,3,5$, and 24 h before labeling pulse. 
therefore not be attributed to the antibiotics themselves. In other histological studies, Gambetti et al. ${ }^{7}$, using light microscopy, found no lesions produced in mouse entorhinal cortex by injection of puromycin $7-36 \mathrm{~h}$ before death. However, at the ultrastructural level, mitochondrial swelling and disaggregation of polyribosomes were observed 7-27 h after puromycin injection, but not after injections of acetoxycycloheximide $^{8}$, a powerful protein synthesis inhibitor similar in structure and mechanism of action to CXM (see ref. 4). Behaviorally, we find no evidence of lasting effects of multiple injections of CXM bilaterally into inferotemporal cortex of a monkey. Four months after 8 injections, there was no obvious deterioration of performance in a visual discrimination task, as might be expected following surgical lesions of this cortical region 10 .

The present findings suggest that localized, reversible blocking of protein synthesis, produced by drugs injected through chronically implanted cannulas, may prove useful in the analysis and localization of higher brain functions, including those previously localized by surgical ablations.

Acknowledgement is made to Prof. S. Hicks, Dapartment of Pathology, for evaluation of histological sections.

Supported by NIMH Grants 12506 and 19622, NSF GB-32409X1, and University of Michigan Phoenix Memorial Project No. 476.

1 AgRanoff, B. W., Effects of antibiotics on long term memory formation in the goldfish. In W. K. Honig and P. H. R. James (Eds.), Animal Memory, Academic Press, New York, 1971, pp. 243-258.

2 Barondes, S. H., and CoheN, H. D., Comparative effects of cycloheximide and puromycin on cerebral protein synthesis and consolidation of memory in mice, Brain Research, 4 (1967) 44-51.

3 Barondes, S. H., Cerebral protein synthesis inhibitors block long-term memory, Int. Rev. Neurobiol., 12 (1969) 177-205.

4 Ennis, H. L., AND Lubin, M., Cycloheximide: Aspects of inhibition of protein synthesis in mammalian cells, Science, 146 (1964) 1474-1476.

5 FleXner, L. B., FleXner, J. B., Roberts, R. B., and de la Haba, G., Loss of recent memory in mice as related to regional inhibition of cerebral protein synthesis, Proc. nat. Acad. Sci. (Wash.), 52 (1964) 1165-1169.

6 Flexner, J. B., Flexner, L. B., Stellar, E., De la Haba, G., and Roberts, R. B., Inhibition of protein synthesis in brain and learning and memory following puromycin, $J$. Neurochem., 9 (1962) 595-605.

7 Gambetti, P., Gonatas, N. K., and Flexner, L. B., The fine structure of puromycin-induced changes in mouse entorhinal cortex, J. Cell Biol., 36 (1968) 379-390.

8 Gambetti, P., Gonatas, N. K., and Flexner, L. B., Puromycin: Action on neuronal mitochondria, Science, 161 (1968) 900-902.

9 Goldman, P. S., Rosvold, H. E., Vest, B., and Galkin, T. W., Analysis of the delayed-alternation deficit produced by dorsolateral prefrontal lesions in the rhesus monkey, J. comp. physiol. Psychol., 77 (1971) 212-220.

10 Gross, C. G., Visual functions of inferotemporal cortex. In R. JuNG (Ed.), Handbook of Sensory Physiology, Vol. 7, Springer, New York 1973, in press.

11 Lim, R., Brink, J. J., AND Agranoff, B. W., Further studies on the effects of blocking agents on protein synthesis in goldfish brain, $J$. Neurochem., 17 (1970) 1637-1647.

12 Mark, R. F., AND WATts, M. E., Drug inhibition of memory formation in chickens. I. Longterm memory, Proc. roy. Soc. B, 178 (1971) 439-454. 